\title{
The Relationship of Professional Competence of Physical Education Sport and Health Teachers to the Implementation of the 2013 Curriculum of Physical Education, Sport and Health in Elementary Schools in Tambaksari District
}

\author{
Muji Tri Handoyo ${ }^{1}$, Anung Priambodo ${ }^{2}$, Noortje Anita Kumaat ${ }^{3}$ \\ 1,2,3 Magister of Sport Education, Universitas Negeri Surabaya, Indonesia \\ Email: mujitrihandoyosor@gmail.com
}

\begin{abstract}
:
The study aims to determine the relationship of PJOK teachers professional competence to the implementation of the 2013 PJOK curriculum in elementary schools in Tambaksari sub-district. This research is a descriptive correlation study, which is the subject of research is all PJOK teachers in Tambaksari sub-district, amounting to 42 teachers. In collecting data using two questionnaires, namely (1) questionnaire to find out the professional competence of PJOK teachers and (2) questionnaire to find out the implementation of the 2013 PJOK curriculum, which was made through Google and distributed through the PJOK teachers working grup (KKG) Tambaksari sub-district. Analysis of the data used is descriptive analysis to determine the percentage of respondents anwers, norm reference assessment (PAN) to determine score criteria, product moment correlation analysis and coefficient of determination. Based on data analysis, obtained the professional competency value of PJOK teachers in Tambaksari district with an average of 40.21 in the classification is quite good, the value of the implementation of the 2013 PJOK curriculum in Tambaksari district with an average of 44.38 in the category is quite good, and correlation coefficient of 0.358 with a significance of 0.020 , when compared with $r$ table then $r_{-}($count $)>r_{-}$tabel $(0.358>0.304)$ so that it can be concluded that there is a significant relationship between the professional competence of PJOK teachers and implementation of the 2013 PJOK curriculum in elementary schools in Tambaksari sub-disrict. Calculation of the coefficient of determination of $12.82 \%$ which means professional competence can affect the implementation of $12.82 \%$ and $87.18 \%$ influenced by other factors.
\end{abstract}

\section{Keywords:}

teacher professional competence; implementation of 2013 curriulum

\section{Introduction}

At this time the curriculum used in the education unit in elementary schools, namely the 2013 curriculum, various efforts have been made by the government to improve the quality of education in Indonesia, one of which is to improve and improve the education unit level curriculum and then implement the 2013 curriculum simultaneously in Indonesia.

Physical education, sports and health is one of the lessons in the 2013 curriculum, is an integral part of national education which has the aim of developing several aspects including: thinking, moving, social, physical fitness, emotional stability, reasoning, behavior healthy life, and introducing a clean environment through learning experiences using selected physical movements performed systematically based on the values of faith and devotion to God Almighty. 
Education in Indonesia is a system whose success is influenced by several factors, according to Riyanto (2017) the implementation of the 2013 curriculum is influenced by three factors, namely (1) teacher readiness, (2) availability of facilities and infrastructure, and (3) student input. These three factors have a relationship for the implementation or implementation of the 2013 curriculum. All of them are integrated for the same goal of improving the quality of education. Teachers have an important role to achieve national education goals, good quality teachers will have an impact on the achievement of national education goals. Competence of a good teacher will produce good and quality students, so that teachers are expected to have good competence. Through education, training, courses, seminars and independent learning using resources.

Physical fitness, in addition to the academic field will also increase. Physical education is different from the sport, because of the physical education teaching physical activity that aims to maintain a healthy body, strengthen muscles, and shape the character of the students, while in sport there are physical activities that require high-level skills and in actual use rules that have been agreed upon. Implementation of learning sports physical education and health in primary schools there are not in accordance with the concept of learning sports physical education and health. (Novianti, 2020)

According to Mulyasa (2007: 26) competence is a set of effective behaviors related to exploration and investigation, also provides perceptions and attention then guides a person to find ways to achieve certain goals effectively and efficiently. By having competence, the teacher can carry out their duties properly so that the results of learning become optimal. According to Paturusi (2012: 105) professional competence is expertise related to the mastery of learning material in the field of study or in-depth and broad subjects encompassing mastery of scientific elements as well as competing in the curriculum material and increasing scientific insights as physical and sports education teachers.

Physical education teacher competence is very necessary for the implementation of teaching and learning activities and can get optimal results, an example when a physical education teacher provides material about soccer games, then he must master knowledge about football and can practice it or demonstrate when teaching material to students. When learning about basic athletic motion material, the teacher can demonstrate to students to practice and can explain the procedures for doing the movements for their knowledge.

Teacher competencies in accordance with PERMENDIKNAS Number 16 of 2007 there are four (4), including: (1) pedagogical competencies, (2) Professional competencies, (3) Personality Competencies, and (4) Social competencies. In this study will discuss the professional competence of physical education, sports and health teachers at the level of elementary school / madrasa ibtidaiyah. The professional competence of Physical education teachers is closely related to mastery of material and knowledge about PJOK, knowledge of core competencies $(\mathrm{KI})$ and basic competencies $(\mathrm{KD})$ of PJOK subjects, development or modification in learning PJOK materials, development of teacher professionalism (PKB), and the use of knowledge knowledge and technology (science and technology) in the learning process.

In addition to the teacher other factors that influence the success of an education that is the curriculum, the curriculum is what governs the implementation of education in Indonesia. Without an education curriculum it will not run well, efficiently and effectively as expected. 
According Mulyasa (2014: 99) defines the implementation of the 2013 curriculum as the actualization of the curriculum in learning and the formation of student character competencies. To implement the 2013 curriculum, teachers are expected to be active in creating and growing various activities that are in accordance with the plan or program.

To achieve learning objectives in accordance with the 2013 curriculum, several learning strategies are needed so that each student can become a learner who grows independently forever by having a positive character attitude that is creative, independent, cooperation, solidarity, tolerance, empathy, leadership and life skills of students so that improve the civilization and self-respect of the Indonesian people. Teachers should need to respond properly according to the level of growth and development of children in both the physical and psychomotor domains. In primary school learning emphasizes the formation of basic movements, the junior high school level emphasizes development, and in senior high school emphasizes strengthening (Roesdiyanto, 2017).

The 2013 curriculum emphasizes the application of a scientific and thematic approach to primary schools with an authentic assessment system emphasizing not only the final results but also the assessment process. In the 2013 curriculum there are four core competencies (KI) including: (KI-I) spiritual or religious attitudes, (KI-2) social attitudes, (KI-3) knowledge, and (KI-4) skills. In order for the learning to be carried out properly, the PJOK teacher should pay attention to the sequence in the learning process contained in Permendikud No. 22 of 2016 which divides the three stages in learning, namely opening activities, core activities and closing activities. The teacher's knowledge of the 2013 curriculum will be useful at the time before implementing learning the teacher makes a plan of learning programs, when the learning process the teacher uses scientific methods with several stages including: observing, asking, trying, associating and communicating in accordance with the material being taught.

Physical education teachers are still found to provide material only text books and most of the time teaching according to their pleasure such as teachers who have soccer competence, almost every day they are taught soccer, who likes rhythmic gymnastics every day rhythmic gymnastics, teachers who have fun playing volleyball then every day the lessons are taught volleyball, so sometimes the material delivered is not in accordance with the existing curriculum but according to the teacher's pleasure.

Previous research that is relevant to the title of my research is research conducted by Raibowo (2019) with the title "PJOK Teachers' Understanding of Professional Competency Standards", a type of qualitative research. From these studies there are similarities in terms of themes, namely professional competence, while the difference is the research is to find out teacher understanding of professional competence. The research conducted by Liakopoulou (2011) in this study aims to find out the qualifications that are considered important by teaching professionals to be effective in pedagogical and teaching work. Research conducted by Golob (2012) the purpose of this study was to determine the relationship between teacher professional development and student achievement on the results of national knowledge assessment. The next research conducted by Kumar (2013) the purpose of this study was to determine the relationship between teacher competence on student achievement and teacher performance.

From several studies have the same research variables that are about teacher competence and implementation in learning, but the differences in the authors examine it focus on teacher professional competence towards the implementation of the 2013 curriculum in elementary schools in Tambaksari sub-district 


\section{Reseach Methods}

In this study using a correlational design that aims to connect two or more variables (Maksum, 2018: 128). The researcher wants to examine the relationship between the professional competence of physical education, sports and health teachers on the implementation of the 2013 curriculum in physical education, sports and health in elementary schools in Tambaksari sub-district as follows:

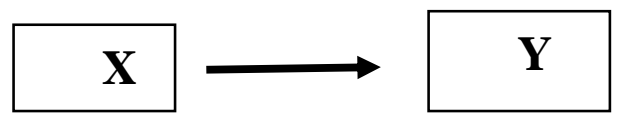

Figure 1. Research Design

Source: Maksum (2018)

$\mathrm{X}$ : Professional competence of physical education, sports and health teachers.

Y: Implementation of the 2013 curriculum in physical education, sports and health in elementary schools in Tambaksari sub-district.

In this study the subject of his research was conducted by total sampling, physical education, sports and health (PJOK) teachers in elementary schools in Tambaksari sub-district of Surabaya, which totaled 42 teachers, the details of which 27 teachers were certified and 15 teachers were not certified. In this study the instruments used were in the form of a questionnaire, there were two questionnaires used namely (1) to determine the professional competence of physical education, sports and health teachers and (2) questionnaires to find out the implementation of the 2013 physical education, sports and health curriculum in elementary schools in Tambaksari sub-district.

This questionnaire is closed because respondents are given a choice of answers consisting of: (1) always, (2) often, (3) rarely and (4) never), respondents can choose one answer that feels right (Sugiyono, 2016: 93). Data analysis test used, among others: descriptive analysis is used to find out the percentage of respondents' answers, the formula used according to (Maksum, 2018: 17), to determine the score criteria using the norm reference reference (PAN) according to (Azwar, 2016: 163)

Data collection that will be used by providing deployment questionnaires through Google forms, after that the test results data analysis using descriptive statistic technigue and in the analysis with the help of computer program SPSS (Statistical Program for Social Science) 22.0 data normality test, linearity test, product moment correlation (Maksum, 2018).

\section{Result and Discussion}

The results of this study are to illustrate data on the relationship of professional competence of physical education, sports and health teachers to the implementation of the 2013 curriculum in physical education, sports and health in elementary schools in Tambaksari sub-district. In this study using a questionnaire consisting of two questionnaires, namely (1) questionnaire to determine the professional competence of PJOK teachers (12 items) and (2) questionnaire to find out the implementation of the 2013 PJOK curriculum in elementary schools in Tambaksari sub-district (27 items) and the results are presented as follows: 


\subsection{Analysis of Teacher Professional Competency Results Physical education, sports and health}

Table 1. Descriptive Statistics

\begin{tabular}{|c|c|c|c|c|c|c|c|c|}
\hline & $\|$ & Ping & Hinn & laing & Bn & \multicolumn{2}{|c|}{ Nyan } & 91 lasian \\
\hline & Gat: & Gati: & Gati: & Gexis & 9256 & 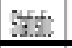 & Silien & $9 \sin 2$ \\
\hline 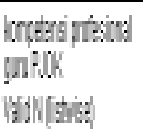 & 47 & 18 & 3) & 4 & 180 & 4.21 & . 10 & 5212 \\
\hline
\end{tabular}

From the descriptive statistical test data using SPSS, the number of respondents $(\mathbb{N})$ is 42 , out of 42 respondents the minimum (smallest) score for professional competence of PJOK teachers is 30 , and the maximum value (48) is 48 . The range value is the difference between the minimum and maximum values equal to 18 , Sum value is the sum of the professional competency values of PJOK teachers from 42 respondents which is 1689 . The average value of 42 respondents or Mean is 40.21 and the standard deviation is 5.082 .

Table 2. Data on the calculation results of PJOK teacher professional competency score

\begin{tabular}{|c|c|c|c|c|}
\hline No. & Category & Qualification & Frequency & presentage \\
\hline 1. & very good & $48<X$ & 4 & $9,52 \%$ \\
\hline 2. & good & 43 s.d 47 & 12 & $28,57 \%$ \\
\hline 3. & pretty good & 38 s.d 42 & 13 & $30,95 \%$ \\
\hline 4. & poor & 33 s.d 37 & 10 & $23,81 \%$ \\
\hline 5. & not good & $x<32$ & 3 & $7,14 \%$ \\
\hline \multicolumn{3}{|c|}{ Total } & 42 & $100 \%$ \\
\hline
\end{tabular}

Based on the data in the table above, it can be seen that $9.52 \%$ (4 teachers) have excellent professional competency categories, as many as $28.57 \%$ (12 teachers) have good competence, as many as $30.95 \%$ (13 teachers) have competence not good and as much as $7.14 \%$ (3 teachers) have poor professional competence. Conclusion The professional competence of PJOK teachers in Tambaksari sub-district with an average of 40.21 in the classification is enough good

\subsection{Analysis of the Results of the 2013 Curriculum for physical education in sports and} health

Table 3. Descriptive Statistics

\begin{tabular}{|c|c|c|c|c|c|c|c|c|}
\hline & $\|$ & fin: & binn & |laiy & By & \multicolumn{2}{|c|}{$\| m$} & Mleign \\
\hline & 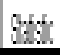 & 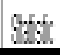 & 82:5: & 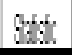 & Gex: & sifis. & 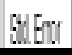 & Bat: \\
\hline  & 4) & I & y & 8 & 1:S4 & 4.8 & IR & 520 \\
\hline
\end{tabular}

From the above data it can be seen that, the number of respondents $(N)$ is 42 , the minimum value is 31 , the maximum value is 53 and the maximum range or difference value minus the minimum value is 22 , Sum or the total number of values is 1864 , the mean or 44.38 , and a standard deviation of 5.333 . 
Table 4. The results of the calculation of the 2013 curriculum implementation data are arranged into interval data

\begin{tabular}{|c|c|c|c|c|}
\hline No & Category & Qualification & Frequency & Persentage \\
\hline 1. & Very good & $53<X$ & 2 & $4,76 \%$ \\
\hline 2. & good & 48 s.d 52 & 13 & $30,95 \%$ \\
\hline 3. & $\begin{array}{l}\text { Good } \\
\text { enough }\end{array}$ & 42 s.d 47 & 15 & $35,71 \%$ \\
\hline 4. & Not good & 37 s.d 41 & 8 & $19,05 \%$ \\
\hline 5. & No good & $\mathrm{X}<36$ & 4 & $9,52 \%$ \\
\hline \multicolumn{3}{|c|}{ Jumlah } & 42 & $100 \%$ \\
\hline
\end{tabular}

By observing the data in the table above, it can be seen that as many as $4.74 \%$ ( 2 teachers) have a very good implementation of the 2013 PJOK curriculum, 30.95\% (13 teachers) have good classifications, as many as $35.71 \%$ (15 teachers ) have a pretty good classification, as many as $19.05 \%$ (8 teachers) have a poor classification, and $9.52 \%$ (4 teachers) have a bad classification. It can be concluded that the implementation of the 2013 PJOK curriculum in Tambaksari sub-district with an average of 44.38 in the category is pretty good

\subsection{Data Analysis}

\section{a. Normality Test}

To find out whether the data is normally distributed or not tested through SPSS analysis and the results are as the following table:

Table 5. Normality Test

\begin{tabular}{|c|c|c|c|c|c|c|}
\hline & \multicolumn{3}{|c|}{ 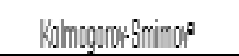 } & \multicolumn{3}{|c|}{ Shariny wik } \\
\hline & Stägisil & if & Sin & Stajistc & if & 80 \\
\hline  & 100 & 42 & $200^{\circ}$ & .967 & $4 ?$ & \\
\hline 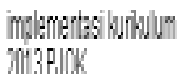 & .114 & 42 & .192 & .67 & 42 & .119 \\
\hline
\end{tabular}

In the professional competency normality test for PJOK teachers, the KolmogorovSmirnova $p$ value of .200 and in the Shapiro-Wilk test were .183. In the 2013 PJOK curriculum implementation, the Kolmogorov-Smirnov test was .192 and the Shapiro-Wilk test was .119. Data of the two groups was declared normal because the p-value was greater than 0.05 .

\section{b. Linearity Test}

Table 6. Linearity Test

\begin{tabular}{|c|c|c|c|c|c|c|c|}
\hline & & & $\begin{array}{l}\text { ind } \\
\text { hases }\end{array}$ & $t$ & lembinger & $\mathrm{F}$ & 대 \\
\hline \multirow{5}{*}{ 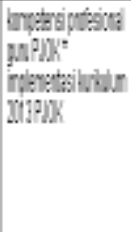 } & Bthen lin & (onfinged) & (a) & 11 & 2154 & 1825 & 90 \\
\hline & & Lex: & 18521 & 1 & 1351 & 118 & .104 \\
\hline & & 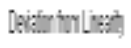 & 5730 & 17 & $z: 6$ & 154 & 176 \\
\hline & Natings & & 620 & ใด & IEK & & \\
\hline & idal & & 160 & 4 & & & \\
\hline
\end{tabular}

From the analysis that has been done, it is obtained the value of $\mathrm{F}$ (deviation from linearity) of 1,511 at a significance of .176 , which means it is not significant so that the relationship between the two variables is declared linear. 


\section{c. Correlation Analysis}

To find out the relationship between the professional competencies of PJOK teachers and the implementation of the 2013 PJOK curriculum in elementary schools in Tambaksari sub-district, a product moment correlation analysis was performed using the SPSS program.

Table 7. Product Moment Correlation Analysis

\begin{tabular}{|c|c|c|c|}
\hline & & $\begin{array}{l}\text { lompetensi } \\
\text { profesional } \\
\text { cunuPJOK }\end{array}$ & $\begin{array}{c}\text { implementasi } \\
\text { kriudum } \\
2013 \text { PJOK }\end{array}$ \\
\hline \multirow{3}{*}{$\begin{array}{l}\text { lompelensi profesional } \\
\text { guv PJOK }\end{array}$} & Pearsun Conelation & 1 & $.358^{\prime \prime}$ \\
\hline & Sig (Rtaled) & & .020 \\
\hline & N & 42 & 42 \\
\hline \multirow{3}{*}{$\begin{array}{l}\text { implemertasikuritulum } \\
2013 \text { PJoK }\end{array}$} & Pearson Conelation & $.358^{\circ}$ & 1 \\
\hline & Sig (2tailed) & .020 & \\
\hline & N & 42 & 42 \\
\hline
\end{tabular}

The results of the correlation analysis of 0.358 at a significance level of 0.020 . Based on the table interpretation guidelines correlation coefficient (table 3.6) correlation coefficient of 0.358 , including the category has a low relationship.

The next step is to compare the $\mathrm{r}$ count with $\mathrm{r}$ table obtained $\mathrm{r}$ count greater than $\mathrm{r}$ table $(0.358>0.304)$ so that the alternative hypothesis $(\mathrm{Ha})$ is accepted and Ho is rejected, meaning there is a relationship between the professional competence of physical education, sports and health teachers to the implementation of the 2013 curriculum physical education, sports and health in elementary schools in Tambaksari sub-district

To find out the contribution of variable $\mathrm{x}$ to variable $\mathrm{y}$, the coefficient of determination is calculated using the following formula:

$$
\begin{aligned}
\mathrm{KD} & =r^{2} \times 100 \% \\
& =(0,358) 2 \times 100 \% \\
& =12.82 \%
\end{aligned}
$$

From the calculation of the coefficient of determination obtained $12.82 \%$, it can be seen that the professional competence of teachers can influence the implementation of the 2013 PJOK curriculum in elementary schools in Tambaksari sub-district and $87.18 \%$ is influenced by other factors including facilities and infrastructure, pedagogical competence, personality competence, social competence and student input.

\section{Conclusion}

Based on the results of research that has been done, the following conclusions can be drawn, There is a significant relationship between the professional competence of physical education, sports and health teachers to the implementation of physical education, sports and health curriculum in elementary schools in Tambaksari sub-district.

It can be concluded based on the results of the relationship between the results of research and previous research that teacher professional competence has a significant relationship with the implementation of the 2013 curriculum, other factors that influence other than professional competence according to Riyanto (2017) include: teacher readiness, infrastructure and student input. 


\section{References}

Arikunto, S. (2016). Prosedur Penelitian Suatu Pendekatan Praktik. Jakarta: Rineka Cipta.

Asmani, J.M. (2011). Tips Menjadi Guru Inspiratif, Kreatif, dan Inovatif. Jogjakarta: Diva Press.

Golob, H. M. (2012). The Impact of Teacher's Professional Development on the Results of Pupils at National Assessment of Knowledge. Procedia - Social and Behavioral Sciences. https://doi.org/10.1016/j.sbspro.2012.06.878 diakses pada tanggal 10 Juni 2020.

Hakim, A. (2015). Contribution of Competence Teacher (Pedagogical, Personality, Professional Competence and Social) On the Performance of Learning. The International Journal Of Engineering And Science.diakses pada tanggal 12 Juni 2020.

Liakopoulou, M. (2011). The Professional Competence of Teachers: Which qualities , attitudes, skills and knowledge contribute to a teacher' s effectiveness? International Journal of Humanities and Social Science. Diakses pada tanggal 10 Juni 2020.

Karahan, a.A.(2012). Physical Education Teacher's views of effective Teaching Methods in Physical Education. Procedia Social and Behavioral Science. 1910-1913. https://www.sciencedirect.com/science/article/pii/S1877042812015303. diakses pada tanggal 13 Februari 2020.

Kumar, V. (2013). The Influence of Teacher's Professional Competence on Students' Achievement. IOSR Journal of Engineering. Diakses pada tanggal 10 Juni 2020.

Maksum Ali, (2018). Metodologi Peneitian Dalam Olahraga. Surabaya: Unesa University Press. Mulyasa, E. (2014). Pengembangan dan Implementasi Kurikulum 2013. Bandung: PT Remaja Rosda karya.

Novianti, D. (2020). Improvement of Physical, Honesty, Discipline and Cooperation in Class IV Elementary School Students through Circuit Training Learning Model. Budapest International Research and Critics in Linguistics and Education (BirLE) Journal. P. 244-250.

Paturusi, A. (2012). Manajemen Pendidikan Jasmani dan Olahraga. Jakarta: Rineka Cipta.

Peraturan menteri pendidikan nasional No 16 Tahun (2007). Standar Kualifikasi Akademik dan Kompetensi Guru. Jakarta: Kemendikbud.

Peraturan Menteri Pendidikan Nasional No. 22 Tahun (2016). Stardar Proses Pendidikan Dasar dan Menengah. Jakarta: Kemendikbud

Riyanto Agus. (2017). Implementasi Kurikulum (2013 dan Tiga Faktor Penunjang Keberhasilannya. (https://www.amongguru.com/implementasi-kurikulum-2013-dantiga-faktor-penunjang-keberhasilannya/) diakses pada tanggal 6 Februari 2020.

Septian Raibowo. (2019). Pemahaman Guru PJOK Tentang Standar Kompetensi Profesional.(https://jope.ejournal.unri.ac.id/index.php/jope/article/view/7868/6779) diakses pada tanggal 20 februari 2020.

Sugiyono. (2016). Metode Penelitian Pendidikan (Pendekatan Kuatitatif, Kualitatif, dan R\&D). Bandung: Alabeta.

Undang-Undang Republik Indonesia Nomor 14 Tahun 2005 Tentang Guru dan Dosen. 